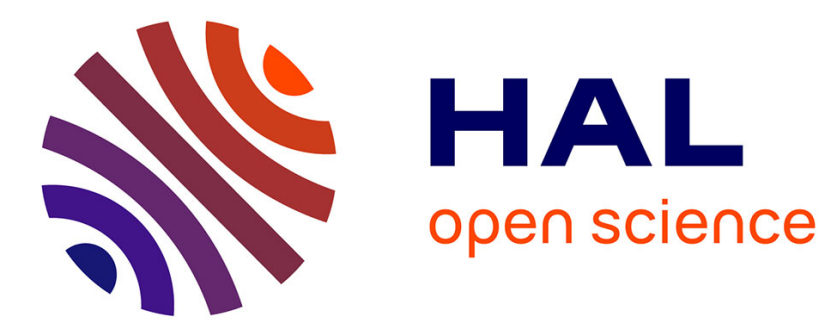

\title{
Determinants of Individual Investment Decisions in Investment-Based Crowdfunding
}

Fabrice Hervé, Elodie Manthé, Aurélie Sannajust, Armin Schwienbacher

\section{To cite this version:}

Fabrice Hervé, Elodie Manthé, Aurélie Sannajust, Armin Schwienbacher. Determinants of Individual Investment Decisions in Investment-Based Crowdfunding. Journal of Business Finance and Accounting, 2019, 46 (5-6), pp.762-783. 10.1111/jbfa.12372 . hal-02065048

\section{HAL Id: hal-02065048 \\ https://u-bourgogne.hal.science/hal-02065048}

Submitted on 26 Nov 2021

HAL is a multi-disciplinary open access archive for the deposit and dissemination of scientific research documents, whether they are published or not. The documents may come from teaching and research institutions in France or abroad, or from public or private research centers.
L'archive ouverte pluridisciplinaire HAL, est destinée au dépôt et à la diffusion de documents scientifiques de niveau recherche, publiés ou non, émanant des établissements d'enseignement et de recherche français ou étrangers, des laboratoires publics ou privés. 


\title{
Determinants of individual investment decisions in investment-based crowdfunding*
}

\author{
Fabrice Hervé \\ Univ. Bourgogne \\ Elodie Manthé \\ Univ. Bourgogne \\ Aurélie Sannajust \\ Univ. Saint-Etienne \\ Armin Schwienbacher \\ SKEMA Business School-Univ. Côte d'Azur \\ Journal of Business Finance and Accounting, forthcoming \\ * Contact address of authors: Fabrice Hervé, Université de Bourgogne, UBFC, IAE DIJON, \\ CREGO, 2 Bd Gabriel, BP 26611, 21066 DIJON CEDEX (France), Email: fabrice.herve@u- \\ bourgogne.fr; Elodie Manthé, Université de Bourgogne, UBFC, IAE DIJON, CREGO, 2 Bd \\ Gabriel, BP 26611, 21066 DIJON CEDEX (France), Email: manthe.elodie@gmail.com; \\ Aurélie Sannajust, Université de Saint-Etienne, COACTIS, Rue Tréfilerie, 42000 SAINT- \\ ETIENNE (France), Email: aurelie.sannajust@univ-st-etienne.fr; Armin Schwienbacher, \\ SKEMA Business School, Department of Finance and Accounting, Avenue Willy Brandt, \\ 59777 EURALILLE (France), Email: armin.schwienbacher@skema.edu. We are grateful for \\ helpful comments and suggestions from Abdulkadir Mohamed, Raghavendra Rau, Andrew \\ Stark (the Editor), Silvio Vismara, the anonymous referee, and seminar and conference \\ participants at the Second Annual Cambridge Conference for Alternative Finance (University \\ of Cambridge Judge Business School), the FMA Europe Conference 2017 (Lisbon, Portugal), \\ the ENTFIN Conference 2016 (Lyon, France), the 2016 Annual AFFI Conference (Liège, \\ Belgium), the ENTFIN Conference 2018 (Milan. Italy), the 2018 Summer Conference on \\ "Financial Implications of Sustainability and Corporate Social Responsibility" (Nice, France), \\ the FMA Asia Conference 2018 (Hong-Kong), and Université de Bourgogne (France).
}




\title{
Determinants of individual investment decisions in investment-based crowdfunding
}

\begin{abstract}
We investigate determinants of investment decisions in investment-based (equity and bond) crowdfunding campaigns, using a novel investment-, investor- and campaign-level database, where equity refers to investments in entrepreneurial start-ups and bonds to large real estate projects. We find that investors who have higher social interactions invest more. Social interactions are important in an equity crowdfunding context but do not affect participation in bond investments. This is consistent with the view that investors' social networks help reduce information asymmetry. Women invest less in the riskiest (equity) investments but more in safer ones (bonds). These findings are better explained by differences in risk aversion than differences in overconfidence between men and women. Overall, the findings contribute to the understanding of how investment-based crowdfunding can be a viable source of entrepreneurial finance and how entrepreneurs' campaign decisions affect investor participation in this new form of entrepreneurial finance.
\end{abstract}

Keywords: crowdfunding, start-up finance, entrepreneurial finance, equity, investment decision, social interactions

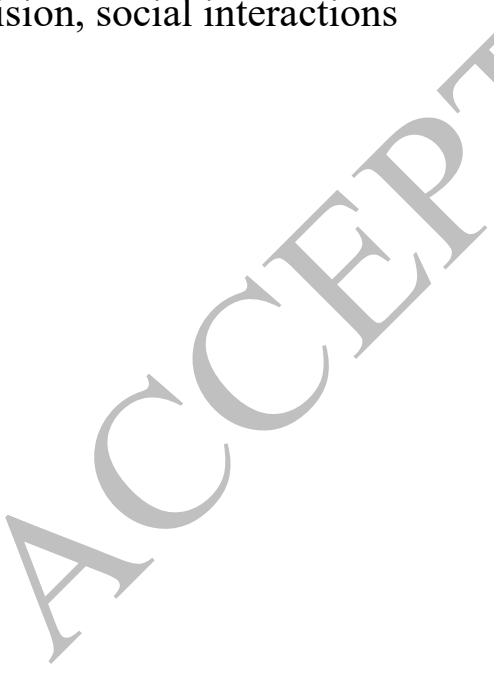




\section{Introduction}

Investors' behavior has been extensively studied in finance. The areas of investigation include personal finance, retirement savings, CEO investment choices, and venture capital finance. By contrast, scholars know little about the decision-making process of non-expert individuals in entrepreneurial finance (Ahlers, Cumming, Günther, \& Schweizer, 2015; Hornuf \& Schwienbacher, 2016; Vismara, 2018). This paper attempts to fill this gap by providing an explanation of equity and bond crowdfunding choices, which involve small, non-accredited investors. More precisely, we investigate the influence of social interactions and gender on investment choices made in equity and bond crowdfunding campaigns.

While reward- and donation-based crowdfunding has quickly become popular, due to Indiegogo in 2008 and Kickstarter in 2009, equity crowdfunding has been slower to develop, notably because of regulatory constraints in most countries in selling financial securities to the general public (Ahlers et al., 2015; Hornuf \& Schwienbacher, 2017b; Vismara, 2018). Crowdfunding has become a viable alternative to traditional sources of entrepreneurial finance and a way to "democratize" finance by providing investment opportunities to innovative startups that, so far, have been restricted to institutional and accredited investors (Agrawal, Catalini, \& Goldfarb, 2015; Kim \& Hann, 2015; Mollick, 2014).

Equity and bond-like (i.e., investment-based) crowdfunding are fundamentally different from other forms of crowdfunding, in that the crowd makes investment rather than consumption- or donation-related decisions. Therefore, current understanding of crowdfunding based on studies of these other forms of crowdfunding has limited applicability to investment-based crowdfunding because incentives and compensation of the crowd are different (Vismara, 2018). The issues investigated so far in the context of reward-based crowdfunding (Agrawal et al., 2015; Butticè, Colombo, \& Wright, 2017; Colombo, Franzoni, \& Rossi-Lamastra, 2015; 
Kim \& Hann, 2015; Marom, Robb, \& Sade, 2016; Mollick, 2014), including the effect of gender, geographic distance, social capital of entrepreneurs, and the local environment in which investors live, must be analyzed separately for investment-based crowdfunding. Only a few studies have examined related issues in equity crowdfunding. Mohammadi and Shafi (2018) show that women tend to invest less in younger, high-tech firms with a high percentage of equity offerings. Vismara, Benaroio, and Carne (2017) examine the effect of gender on the interaction between demand and supply of equity capital. Vismara (2016) analyzes the impact of social capital of the entrepreneur. To the best of our knowledge, the impact of social interactions of investors has not been examined in the context of equity crowdfunding. In addition, equity and bond crowdfunding inevitably affect the types of individuals who participate in these campaigns, which differ from the forms of crowdfunding previously investigated.

To develop precise hypotheses and, thus, organize our analysis, we rely on behavioral finance and modern finance theories that help explain the decisions of individual investors and the possible biases to which they may be subject. In particular, we derive predictions on how social interactions may affect investment decisions. To provide suitable tests, we investigate this effect on equity and bond crowdfunding campaigns. We expect a differentiated impact of social interactions on equity and bonds investment choices because these two types of securities are intrinsically different and have, by nature, different levels of risk. Moreover, as a means to better understand gender differences we explore whether differences in risk aversion and overconfidence between individuals can affect investment decisions. We also exploit both sets of crowdfunding types, equity and bond, which differ in risk, to explain gender differences.

We use a unique database to examine the behavior of investment-based crowdfunders. We obtain all investments made on the French platform WiSEED in equity and bond crowdfunding 
campaigns since its start in 2009. To the best of our knowledge, this database provides more information than what other studies have used so far. Our database contains 10,142 individual investment decisions, $73.1 \%$ of which are equity crowdfunding investment decisions. The database contains information on individual investors, including their date of birth, gender, and location of domicile. We are able to track all the investments made by every individual, so we know when someone has invested, how much in which campaign, when, and in which other campaign(s) he or she has participated. From the location of investors, we are further able to combine our investment database with other databases to assess local conditions that are helpful for testing our hypotheses. In addition to investor-level information, our database contains various information on campaign structure, start-ups, and projects. On the WiSEED platform, bond-like securities are only offered in one sector: real estate.

We find that social interactions exert a strong influence on the investment made by crowd investors. More precisely, crowd investors with more daily social interactions invest more than others. In particular, we observe a stronger effect of social interactions for equity crowdfunding than for bond crowdfunding. This is in line with an information-based explanation of investments as proposed by Hong, Kubik, and Stein (2004) in the context of stock markets and by Vismara (2016) in the context of equity crowdfunding. Investors process and extract information during their social interactions. The more they interact, the more they obtain information through their interpersonal ties, the less they are subject to information asymmetry for a given project, and the more they invest. This is what Granovetter (1983) calls the "strength of weak ties." To the best of our knowledge, our study is the first to document this issue for equity crowdfunding.

Moreover, we document several gender differences. We find that women invest less in riskier investments, not only in numbers but also in amounts per campaign. Part of this is due to the 
higher minimum ticket of real estate bond-like crowdfunding campaigns, and women make larger investments than men in less risky projects. Additional analyses show that these findings are better explained by differences in risk aversion between men and women than by differences in overconfidence. Overall, our findings help explain how investment-based crowdfunding, and in particular equity crowdfunding, can be a viable source of entrepreneurial finance and how entrepreneurs can attract investors.

Our study offers several contributions. First, echoing Ahlers et al. (2015), Block, Colombo, Cumming, and Vismara (2018), and McKenny, Allison, Ketchen, Short, and Ireland (2017), we investigate supply-side effects of equity crowdfunding. As Ahlers et al. (2015, p. 975) note, understanding of "the other side of the equation," or the decision-making process of individual investors that takes place in crowdfunding, is limited, though crucial, for entrepreneurs relying on equity crowdfunding. Moreover, we explore the supply side of the bond crowdfunding. Second, we examine the effects of social interactions of crowdfunders in both equity and bond crowdfunding. We find that social interactions of crowdfunders are particularly important to understand investment decisions and that these interactions have a positive influence on individual investments. In particular, social interactions exert a strong influence in the context of equity crowdfunding but are unimportant in bond crowdfunding. To explain this differential impact, we rely on social network theory, which matters for equity crowdfunding (Vismara, 2016). To date, research on the effect of social networks in the crowdfunding literature has adopted the perspective of the entrepreneur. We consider the point of view of the investor. Third, whereas recent studies examining gender effects (Marom et al., 2016; Mohammadi \& Shafi, 2018; Vismara et al., 2017) rely on an algorithm to assess the gender of crowdfunders, we have exact information on gender, as well as age and where they live. In particular, we are able to assess the impact not only on overall funding success but also on the factors inducing individual investors to participate in the financing of crowdfunded start-ups. Fourth, the 
inclusion of bond crowdfunding in our analysis offers a unique opportunity to investigate whether the investment choices in rather different assets in terms of risk and return (equity and bond) are driven by risk preferences of crowdfunders or by a behavioral bias (i.e., overconfidence).

The paper continues as follows. After a brief literature review, we develop our hypotheses. Then, we discuss the empirical setting and describe the unique data used. Next, we present our empirical results. The final section discusses the results, presents limitations of our study, and concludes.

\section{Literature review and hypotheses development}

\subsection{Literature review}

Research identifies several determinants of success of a crowdfunding campaign, including the size of the founder's social network, the presence of a presentation video, the social capital of founders, the desired funding goal, and the duration of the campaign (Frydrych, Bock, Kinder, \& Koeck, 2014; Giudici, Guerini, \& Rossi-Lamastra, 2013; Kuppuswamy \& Bayus, 2013; Mollick, 2014). Geographic location plays less of a role than for other forms of entrepreneurial finance, as crowdfunding alleviates the role of distance in early-stage financing (Agrawal et al., 2015). Lin, Prabhala, and Viswanathan (2013) show that social networks can reduce information asymmetry and thereby increase the probability of funding. Social interactions between investors contribute to the success of a campaign. Vismara (2018) finds evidence of information cascades in equity crowdfunding, in which early investors help attract follow-up investors. Although these studies have used data on individual investments, our data enable us to extend the scope of analysis by examining not only campaign-level success outcome but also (and mainly) the impact of investor characteristics on investor-level decisions to invest. 
As Vismara (2018) stresses, equity crowdfunding distinguishes itself from the other forms of crowdfunding and, in particular, from reward-based crowdfunding on three main aspects. First, the underlying motivations are different. Equity crowd investors are seeking financial return and thus are financially motivated (Cholakova \& Clarysse, 2015). Reward-based crowdfunders are often pursuing broader objectives that may include non-pecuniary benefits (Schwienbacher \& Larralde, 2010). Second, the number of shares to be sold in an equity crowdfunding campaign is limited, which contrasts with reward-based crowdfunding in which entrepreneurs typically accept as many orders as possible. This limitation affects funding dynamics (Hornuf \& Schwienbacher, 2017a). Third, the average amount collected and the type of proponents involved differ. Reward-based crowdfunding involves mostly individuals and small amounts (typically below USD 10,000), whereas equity crowdfunding campaigns are led by companies that seek much larger amounts on average (Vismara, 2018).

\subsection{Hypotheses development}

According to modern finance theory, an individual investor facing an investment decision should engage in a rational decision-making process. This process involves many steps, including defining the problem, identifying the criteria, weighting the criteria, generating alternatives, rating each alternative on each criterion, and computing the optimal decision (Bazerman \& Moore, 2009). Prior research, however, shows that people do not always decide according to such a rational model (see Kahneman, 2011). Simon (1957) proposes a way to accommodate this departure from the prescriptive decision analysis: because human rationality is bound, the best way to understand the decision-making process is to determine how decisions are made. When people must make decisions, especially decisions with uncertain outcomes, they tend to rely on heuristics (Tversky \& Kahneman, 1974). Heuristics are simple rules of thumb that help people simplify decision making and avoid cognitive overload induced by 
complex choices. Heuristics influence investment choices of individuals (Agnew, 2006; Benartzi, 2001) but can also lie at the origin of biases (Tversky \& Kahneman, 1974). In this paper, we follow this and other approaches and examine the decision process of individual investors in the context of investment-based crowdfunding.

\subsubsection{The impact of social interactions}

In the context of retirement savings, Duflo and Saez (2002, p. 122) indicate that "the literature on informational cascades [...] provides reasons why information (correct or not) obtained from co-workers may be an important factor in deciding whether to participate and how to invest - giving rise to peer effects." It is reasonable to assume the same is true for crowdfunding investments. Word-of-mouth communication contributes to explain investors' behaviors in financial areas, including crowdfunding. Vismara (2018) finds evidence of information cascades among crowdfunders at an aggregate level. Prior research also shows that social interactions affect investment and trading decisions of individuals (Grinblatt \& Keloharju, 2001; Hong et al., 2004, 2005; Ivković \& Weisbenner, 2007; Kaustia \& Knüpfer, 2012). These studies suggest that stronger social influences result in higher participation rates in the stock markets.

An important determinant of this communicational effect lies in sociability. If people do not interact regularly or easily, social influence cannot take place. Hong et al. (2004) advocate that people extract information from their interactions with other people, through informal connections. Their empirical findings confirm this intuition and put forth the "strength of weak ties" (Granovetter, 1983). In this vein, Ivković and Weisbenner (2007) find that the correlation between an individual investor's stock purchases and that of his or her neighbors increases with the sociability in the area of living. $\mathrm{Ng}$ and $\mathrm{Wu}$ (2010) observe the social influence on investments in risky assets, with peer effects resulting from social interactions (i.e., the 
influence of word-of-mouth effects) being more prevalent in buys than in sales. Hvide and Östberg (2015) confirm this influence of social interactions on investments in a given stock, whether it is a buy or sell. This leads to the following hypothesis:

H1a (social interactions and investment): The amount invested increases with the crowd investor's level of sociability.

The impact of social capital in the context of crowdfunding has largely been assessed from an entrepreneur perspective (for a review in the context of reward-based crowdfunding, see Skirnevskiy, Bendig, \& Brettel, 2017) rather than a crowd investor one. Vismara (2016) extends this analysis to equity crowdfunding. He shows that the larger the social network of an entrepreneur, the higher is the probability of success of an equity crowdfunding campaign.

Social interactions are included in social capital and reflect a structural dimension of social capital (Tsai \& Ghoshal, 1998). As Guiso, Sapienza, and Zingales (2004) evidence, a higher level of social capital implies a higher level of trust in others and, in our context, in entrepreneurs undertaking an equity crowdfunding campaign. We therefore expect that a higher social capital will have an effect on the type of investments crowd investors make. Building on social network theory, Vismara (2016) advocates that the social network of an entrepreneur can help reduce information asymmetry and acts to signal the quality of a project. In the same vein, Polzin, Toxopeus, and Stam (2018) note that the development of interpersonal ties between people affects the perceived moral hazard in the context of crowdfunding. In the context of private equity, Freiburg and Grichnik (2012) find that social ties can reduce information asymmetry and, thus, uncertainty. Analyzing seed-stage investments made by venture capitalists and business angels, Shane and Cable (2002) indicate that social ties are an important mechanism through which to overcome information asymmetry. This is in line with explanations of investor behavior based on social interactions. Investors with a higher level of 
social interactions are subject to less information asymmetry, and consequently, they are more prone to invest money in a given project when they decide to invest.

Given this difference in the level of uncertainty, we expect that social interactions play a larger role in equity-like investments than bond-like investments. Along this line, Shane and Cable (2002) argue that social ties are less important when uncertainty is lower. In other words, social interactions likely have a weaker effect on less uncertain investments, which are related to real estate projects funded through bonds. This leads to the following hypothesis:

H1b (social interactions and campaign type): The positive effect of the crowd investor's sociability on the amount invested is stronger for equity crowdfunding than bond crowdfunding campaigns.

\subsubsection{The influence of gender}

We predict that men and women make different investments. One possible explanation for different individual behaviors between men and women is risk aversion, which leads more riskaverse individuals to make fewer and smaller investments in risky assets. Croson and Gneezy (2009) find that women exhibit higher risk aversion than men regardless of the setting, whether experimental or in real conditions of investment. In the field of investment, several studies show that women invest less in risky assets than men (Agnew, Balduzzi, \& Sunden, 2003; Sunden \& Surette, 1998). Under risk aversion, this is because differences in risk preferences cause women to dislike risk more than men (for a related discussion, see Markowitz, 1959); as a result, they also undertake fewer investments. This leads to the following hypotheses:

H2a (gender and investment): Female crowdfunders make fewer and smaller investments than male crowdfunders. 
H2b (gender and risk): Male crowd investors invest more in riskier equity crowdfunding securities than female crowd investors, who invest more in safer bond crowdfunding campaigns.

\subsubsection{The influence of risk aversion and overconfidence}

An alternative explanation for the same effects as derived in $\mathrm{H} 2 \mathrm{a}$ and $\mathrm{H} 2 \mathrm{~b}$ is differences in overconfidence between men and women. From a review of economic literature, Croson and Gneezy (2009) conclude not only that women are more risk averse than men but also that men are more overconfident in their success in uncertain situations and that overconfidence could explain the observed differences in risk attitudes between women and men. In the field of finance, Barber and Odean (2001) and Agnew et al. (2003) find that men trade more than women. In the same vein, Estes and Hosseini (1988) conclude that women have less confidence than men in their investment decisions. Therefore, gender influences people's level of confidence, which implies, for example, that men would overestimate the probability of success of a nascent firm and women would make fewer significant investment decisions (Huang \& Kisgen, 2013). Women participate more in retirement plans and invest less in company stocks, which in their setting means that they make better decision (Agnew, 2006). Becker-Blease and Sohl (2011) find similar results for business angels and, in particular, validate the hypothesis that the participation of women in venture capital investment decisions leads to fewer investments; in other words, women invest less than men. The authors advocate that overconfidence can explain this phenomenon. In the same vein, Harrison and Mason (2007) observe that women business angels are less active than men (on average 3.3 investments during the period from January 2001 to mid-2004 for men vs. 2.6 for women). Huang and Kisgen (2013) confirm these results for CEOs of U.S. firms, finding that female executives are less likely to make acquisitions than male executives. Similarly, Faccio, Marchica, and Mura 
(2016) conclude that the hiring of female CEOs leads to less corporate risk-taking.

In the area of finance, many studies find that overconfidence leads to suboptimal decisions. Statman, Thorley, and Vorkink (2006) and Glaser and Weber (2007) show that overconfidence causes excessive trading volume. Mitchell and Utkus (2006) and Benartzi (2001) conclude the same in the area of retirement savings, finding that people make poor investment decisions when they are overconfident. CEOs can also be overconfident and thus overinvest (when they have excess cash available) or undertake too many mergers (Malmendier \& Tate, 2005, 2008). Zacharakis and Shepherd (2001) show that investment decisions of overconfident venture capitalists are biased, leading them to finance inappropriate ventures. In summary, overconfidence often affects people in their financial decisions, which are naturally complex, regardless of whether they are experts or not.

To disentangle these two explanations, we rely on research in the field of social psychology. Dunning, Griffin, Milojkovic, and Ross (1990) and Vallone, Griffin, Lin, and Ross (1990) conduct experiments that show that people are overconfident in predicting the behavior of their peers. In a crowdfunding investment decision, people must choose projects that will be the most appreciated by their peers on the crowdfunding platform; otherwise, projects may not get funded in the first place. Rather, a project will be funded only if enough people finance it, and they will do so only if they believe that other people will consider it a valuable project. That is, individuals must guess others' behavior. In the context of crowdfunding, a failed campaign is one that does not raise the desired amount of funds. In this case, overconfident investors will more likely finance unsuccessful projects because their overconfidence in predicting peers' behavior leads them to select less desirable projects. Failing to find support for this prediction would lead us to consider that the excessive investing behavior of men is due to risk preferences (i.e., our alternative hypothesis). Thus: 
H3 (gender and outcome): Men finance projects that fail to achieve their funding goals more often than women.

In testing these hypotheses, we control for different factors that may affect our proxies. In particular, we offer other possible explanations for differences in investment behavior. One is age of the investor. Older investors may invest in less risky assets because they are closer to retirement than younger investors. Whenever possible, we include proxies for population and the wealth and education of the local population. In particular, wealth and education are likely to affect the capacity of individuals to make investments. Because we are unable to obtain information on these factors at the individual level, we rely on proxies measured at the local population level to control for them.

Similarly, we control for local factors other than sociability that could affect investor choice. In particular, we control for the influence of the social networks of the entrepreneurs, which can exert a positive impact on the outcome of a campaign in equity crowdfunding (Vismara, 2016). Finally, we include several project-specific characteristics (and several fixed effects) that are likely to affect the level of investment; we introduce these subsequently.

\section{Empirical setting and data}

\subsection{Empirical setting: WiSEED}

Our unique data set comes from WiSEED, a France-based equity crowdfunding platform. The WiSEED platform was launched by two co-founders in 2009 as the first French equity crowdfunding platform, with headquarters based in Toulouse. The aim of the platform was to help finance young companies through crowdfunding to reduce the so-called equity gap (Cosh, Cumming, \& Hughes, 2009). While the market for equity crowdfunding has become highly competitive, it is also concentrated around two main platforms (WiSEED and Anaxago), which 
represent more than $80 \%$ of today's French equity crowdfunding market. ${ }^{1}$

According to the French regulator AMF (Autorité des Marchés Financiers), soliciting equity from the crowd without a prospectus was forbidden until October 2014, unless it complied with given exemptions (Hornuf \& Schwienbacher, 2017b). The main exemption limited the total offer to less than EUR 100,000 for a given year. Moreover, if investors were pooled in a dedicated holding that syndicates investors, a limit of 149 people was imposed. These conditions constrained the development of a broader equity crowdfunding market in France that could address interests of larger crowds.

In October 2014, the limit of the total offer was increased to EUR 1 million. The government also created a new legal status for platforms: Participative Investment Advisor (Conseiller en Financement Participatif) for equity crowdfunding platforms and Participative Investment Intermediary for crowd-lending platforms. Under this new legal form, start-ups can raise up to EUR 1 million per venture per year. In addition, there is no longer a limit in the number of investors or how much each individual can invest. However, there is also no "smart investors" status, as requested in the United Kingdom and the United States, that requires investors to pass an assessment survey.

Until October 2015, 85 projects raised more than EUR 37 million from approximately 56,000 members on WiSEED. All members are individuals; members cannot be institutional investors. The minimum ticket for individual investors varies by projects, but most start with EUR 100 per share. That means that individuals can choose directly which projects they want to invest in, from an amount of money small enough to allow almost everyone to participate and diversify across multiple projects. For each successful campaign, WiSEED creates a specific

\footnotetext{
${ }^{1}$ See https://www.wiseed.com/fr, based on data from http://tousnosprojets.bpifrance.fr/.
} 
investment vehicle in which investors are pooled together. The collected funds invested in the vehicle are then directly invested in the start-up as a single shareholder. The dedicated vehicle is represented by one WiSEED team member during the period of investment in the start-up. All the holdings take the legal form of a limited liability company ("Société par actions" in French) governed by French law. As we mentioned previously, there is no limit in the number of investors who can join the holding company as shareholders.

WiSEED's core responsibilities are to select start-ups seeking funding, undertake due diligence, help them collect money, and follow them until a medium-term exit horizon. The WiSEED team consists of 30 members located in both the Toulouse and Paris offices. WiSEED receives more than 1,200 projects every year. Every week, an internal selection committee meets to select start-ups that are within the investment scope of WiSEED. This scope is defined as follows: young innovative ventures, with a dedicated team, with a proof of concept done, with a go-to-market identified. ${ }^{2}$ WiSEED focuses mainly on start-ups active in the sectors of biotechnology or clean tech. Moreover, these start-ups should have a social, a societal, or an environmental impact.

The selected ventures are then presented on the website (168 in the first half of 2015). Each firm has its own online profile with a video, a resume of its activity, some financial data, and a corporate presentation. WiSEED relies on its members to select the final projects. In this final selection, called the "e-vote" phase, members are asked to vote on 11 objective criteria (product \& services, team, regulation, market, competition, intellectual property, business model, clients, social responsibility, financial coherence, and commercial action), give their investment intention, and possibly leave a comment on the public forum. After four weeks, WiSEED allows the project to officially launch its campaign if it has collected more than 100

\footnotetext{
${ }^{2}$ See https://www.wiseed.com/fr/startups/lever-des-fonds.
} 
voters and more than EUR 100,000 of investment intentions, including a minimum of $25 \%$ expressed by current investors. However, before the official launch, the platform undertakes a final, extended due diligence on these companies. The venture valuation is negotiated only at this time. This due diligence occurs offline, by WiSEED analysts who check items such as financial consistency and intellectual and industrial property. Only then can the company launch the campaign.

Firms that meet these criteria are eligible to start their fundraising campaign, which lasts between one and three months. The actual length of the campaign depends on the financial needs of the firm and the "buzz" around the campaign. The investment documentation goes only to members of WiSEED who completed their registration, which requires them to send a scan of their ID card, a formal proof of residence, and a completed "Know Your Customer" form, which ensures that WiSEED collects information on its members. Before the campaign is launched, a minimum threshold, a "desired" funding goal, and a maximum limit are defined with the entrepreneur. The goal is what the entrepreneur would like to raise, and the minimum is the threshold above which the platform considers the fundraising campaign valid.

With regard to the funding goal, WiSEED applies a hybrid funding model, which mixes a "keep-it-all" funding model and an "all-or-nothing" model (for a discussion on differences and implications for entrepreneurs, see Cumming, Leboeuf, \& Schwienbacher, 2014). In other words, the funds raised would be paid out to the firm, even if the funding goal is not reached. However, if funds raised are below the minimum threshold, all the money is returned to the investors.

Moreover, while equity offers have existed since 2009 on the platform, WiSEED has offered bond-like investments in very large real estate projects since 2011. Individuals can therefore choose between more risky investments in start-ups through equity and in less risky securities 
in the form of bonds (typically offering a 10\% annual interest during a 12-36-month period). These projects tend to be large, as many require several millions of euros. The bulk of these projects are bank financed, but real estate companies need to provide some minimum equity finance to secure the bank loan. Crowdfunding allows real estate companies to raise between EUR 100,000 and 5 million from crowd investors, to finance a part of this equity. In other words, crowd investors do not invest directly in a real estate project but rather help finance a property developer or a real estate company for a specific project. Crowd investors then hold bonds that are junior to the bank loan but senior to the real estate company's claims, In addition, no e-voting takes place, so the platform is solely responsible for due diligence before campaign launch. The way the platform advertises the offerings, manages investments, and interacts with crowd investors differs little from equity crowdfunding campaign. After the fundraising is closed, the real estate company keeps crowd investors informed through monthly reports sent via the platform.

Although real estate bond crowdfunding resembles lending-based crowdfunding because of the use of interest-generating bonds, the two processes are quite different. Here, the bonds issued to investors serve to finance the equity part that entrepreneurs must provide to obtain the bank mortgage for funding the major part of their real estate projects. Thus, these bonds have lower priority than the bank mortgage (but higher priority than the entrepreneur's equity) in case of project failure, giving it a quasi-equity property. Still, from the perspective of investors on WiSEED, investment in these bonds remains safer than investment in equity crowdfunding. First, real estate projects have a significant amount of collateral because the bulk of the funds is invested in fixed, long-term assets (i.e., property). Second, while these bonds have lower priority than bank mortgages in case of bankruptcy, their maturity (maximum of 36 months) tends to be shorter than bank mortgages. Thus, bonds tend to be repaid earlier, thereby reducing risk. 


\subsection{Data and summary statistics}

\subsubsection{Data}

Our initial set of campaigns comprises all the campaigns that took place on WiSEED since its start, which includes 107 campaigns ( 81 equity campaigns and 26 bond campaigns) undertaken by 64 different start-ups and 26 real estate projects. Campaigns that were still ongoing as of September 2015 are not included, leading to the exclusion of three equity and five bond campaigns. We also withdrew two equity crowdfunding campaigns that failed to raise even the minimum threshold set by the platform (see Section 3.1 for more details) for which no information is available to us. This led to a final sample of 97 campaigns that have taken place since 2009,76 of which are equity crowdfunding campaigns and 21 real estate crowdfunding campaigns. ${ }^{3}$ The sample includes both campaigns that achieved their desired funding goal (which is different from the minimum threshold set by the platform) and those that did not. This final sample includes more than 10,000 individual investments.

For each crowdfunding campaign, we collect information on each investment made, including the exact date of investment and the amount invested. We also obtain detailed information on almost all the investors (99\%), including gender, date of birth, location (postal codes and name of town), and the entire set of investments they made across the different campaigns on WiSEED. For the start-ups and real estate projects, we obtain information on the minimum ticket, location of the start-up (available only for bond investments), year of incorporation (not applicable for real estate projects), industry, and desired funding goal.

We complement these data from WiSEED with other sources of information, in line with our

\footnotetext{
${ }^{3}$ In the case of equity crowdfunding, we have more campaigns than start-ups because some start-ups have run more than one campaign. As robustness, we also ran the entire analysis excluding follow-up campaigns. The results remain qualitatively the same as presented in Section 4.
} 
hypotheses and control variables. To control for the influence of entrepreneurs' social networks, we use a measure based on the number of connections each entrepreneur had on his or her LinkedIn profile. This measure was first proposed by Colombo et al. (2015) in a rewardbased crowdfunding context and adopted by Vismara (2016) for equity crowdfunding. We use data from the French National Statistical Agency (called INSEE) to obtain information on local conditions of investors based on postal codes, including population, sociability, regional wealth, and regional education level. Table 1 provides detailed information on all the inyestorlevel, firm-/project-level, location-level, campaign-level, and investment-level variables.

\section{[TABLE 1 ABOUT HERE]}

Researchers rely on different sociability measures. Hong et al. (2004) use church attendance, the number of neighbors that people visit on a weekly basis, and the number of neighbors they know. Ivković and Weisbenner (2007) consider households' state of residence and assign them a sociability measure. Their measure, which comes from Putnam (2000), classifies sociable (non-sociable) households according to a sociability score above (below) the median score in their sample. Guiso et al. (2004) use regional data on blood donation to assess social capital. The rationale for using aggregate data is that social capital and sociability of individuals are also affected by behavior observed in their neighborhood. Individuals will spend more time in social activities if their neighborhood or region is generally engaging in social activities, which facilitates social interactions and encourages individuals also to spend more time in social activities. We follow a similar approach and link individuals' location with a sociability measure provided by INSEE. The measure is the number of minutes per day a person spends in social interactions (having direct conversations with family, relatives, neighbors, or others 
in a non-professional environment). ${ }^{4}$ This measure is available for different ranges of population sizes in France, as detailed in Table 1. It is further disaggregated by gender, with women having higher values than men for all population ranges. We match these values to each investor by gender and population of postal code to construct our measure Sociabilityl. To check for robustness, we use a second measure, Sociability2, that takes the percentage of the local population that engages in social activities every day. By construction, the values of both measures are not abstract indices but have economic meaning, so we do not standardize them.

\subsubsection{Descriptive statistics}

Table 2 provides basic summary statistics of our final sample. Panel A reports investment-level statistics, Panel B reports campaign-level statistics for equity crowdfunding campaigns, and Panel C lists campaign-level statistics for bond crowdfunding campaigns.

\section{[TABLE 2 ABOUT HERE]}

Panel A provides information on the level of sociability of investors. We obtain this information for investors located in France only, as we rely on statistics from INSEE that are only available for France (some of the observed variation in the number of observations is also due to missing postal codes of some members, which leads to small differences in sample sizes used in the multivariate analyses). We find that people have a mean time of social interactions of 11.4 minutes a day and $17.0 \%$ of the population engages in any social activity on a daily basis. These figures are close to the national averages computed by INSEE. Of the investments, $93.0 \%$ are made by men and only $7.0 \%$ by women. This is in sharp contrast with observations in the context of reward-based crowdfunding. Marom et al. (2016) find that $44 \%$ of investors

\footnotetext{
${ }^{4}$ More precisely, the sociability index measures the time a person spends on average on the following activities: entertainment with friends, direct communication within the family, remote communication within the family, religious activities, and civic or associational activities.
} 
on Kickstarter are women. Instead, our figure is in line with reports in the world of finance. In the area of corporate investments, Huang and Kisgen (2013) report that 94\% of CEOs are men; Graham, Harvey, and Puri (2013) conclude the same using statistics for U.S., Asian, and European CEOs and CFOs. In our sample, we find that all start-ups are run by male CEOs. Vismara (2016) also reports high values, though he observed some female CEOs in his sample. He obtains a proportion of male CEOs of $89 \%$ on the U.K.-based platforms Crowdcube and Seedrs. Vismara et al. (2017) document similar figures (83\%) for the platform Seedrs. Adopting the viewpoint of fund providers leads to a similar conclusion. Harrison and Mason (2007) indicate that the proportion of women business angels varies between $0 \%$ and $10 \%$. Becker-Blease and Sohl (2011) provide similar statistics. Thus, the nature of investors (i.e., whether they are professionals or "unsophisticated" individuals) does not explain the strong male-based result we observe herein.

The average investor age (measured at the investment level) is 43.4 years, with a minimum of 18 years (as members need to be 18 to invest). Seventy-three percent of investments are in equity crowdfunding; however, this large percentage is also due to the fact that bond investments have become possible only recently. Thus, we need to control for time effects in the multivariate setting. The vast majority of investments are also made by individuals living in France (92.1\%), with the two next most represented countries being Switzerland (1.7\%) and Belgium (1.4\%). The remaining $4.8 \%$ comes from a large range of other countries. ${ }^{5}$ Thus, investors are close to their investments. The average amount invested is EUR 2,149.3; however, there is a large variation. The observed minimum is driven by the minimum ticket imposed by WiSEED, while a few exceed the average amount. Finally, approximately 0.48 other

\footnotetext{
${ }^{5}$ Equity crowdfunding platforms in France are not authorized to translate their websites in another language. Doing so would be considered a direct investor solicitation, which is forbidden by French regulation of equity crowdfunding. Therefore, all the web pages of WiSEED are in French, which limits foreign investments. Most of the foreign investors are either French expats or French-speaking people. Furthermore, there is a special rule for U.S. residents: Even if they want to invest via the platform, they must do it through a French bank account for fiscal reasons. This extra requirement makes investments by U.S. residents unlikely.
} 
investments are made on the same day in either the same campaign or another campaign on WiSEED (with a maximum of 32). This number is much smaller than similar measures calculated for reward-based crowdfunding platforms (Kuppuswamy \& Bayus, 2013). This difference is due to the distinct market of equity crowdfunding, which is limited to specific start-ups, while reward-based crowdfunding platforms are more suitable for a larger, projectbased set of entrepreneurial initiatives. Thus, we expect collective attention and "blockbuster" effects to be small on WiSEED. ${ }^{6}$

Panel B of Table 2 shows statistics at the campaign level (i.e., we use one observation per campaign to calculate statistics, leading to 76 observations) for equity crowdfunding campaigns. Firms are relatively young (3.67 years at time of campaign launch). The average entrepreneur has 387 LinkedIn connections. This number is slightly higher than the 330 connections reported by Vismara (2016) for his sample on the U.K.-based platform Crowdcube. This lack of major difference suggests that LinkedIn is a widely used service also outside English-speaking countries. The average minimum ticket is approximately EUR 1,000, with values ranging from EUR 100 to EUR 5,000. There is a strong difference between median and mean minimum tickets, suggesting that the distribution of equity campaigns' minimum tickets is positively skewed. A few equity campaigns have high minimum tickets. The total amount raised is slightly more than EUR 150,000 from 92 investors on average, while the "desired" funding goal is EUR 244,039.50. Thus, only $23.7 \%$ achieve their desired goal. However, because campaigns are run under the keep-it-all funding model, they are able to keep the pledges they have collected. From the platform perspective, the number of campaigns launched every year increases strongly. For 2015, note that our sample covers only part of the year; the platform expects twice as many campaigns in 2015 as in 2014. Most start-ups are

\footnotetext{
${ }^{6}$ Variation exists in the number of observations across variables, with the largest variation being for the last six variables on local population factors. This is because these variables can only be calculated for investors located in France.
} 
active in the sectors of Environment (30.3\%), ICT (26.3\%), and Industry \& Service $(26.3 \%)$. A single start-up is active in real estate (representing $2.6 \%$ of the sample), though it is not a real estate project in the form considered in real estate crowdfunding. As we clarify subsequently, the fact that there is only one start-up active in the real estate sector makes the simultaneous inclusion of sector dummies and the dummy variable Investment Type ( 1 =Equity) problematic at times because of almost perfect collinearity in multivariate regressions.

Two-thirds of the real estate bond campaigns achieve their desired funding goal (Funded Dummy $=0.667$; see Panel C of Table 2), which is clearly higher than that for equity. Bond campaigns also have higher minimum tickets (EUR 1,000 for all campaigns so far), raise larger amounts on average (EUR 384,904.80 from 116 individuals), and have larger goals on average (EUR 432,904.80). Because bond campaigns have only been possible since 2013, the bulk of the campaigns has been run only recently.

Finally, Table 3 shows a correlation matrix for the main variables at the investment level. It indicates that the two sociability measures are highly correlated at $70.1 \%$. This high value is likely because one is a transformation of the others, instead of capturing two completely separate dimensions of sociability. All other correlations are weak, except those measured at the local levels (rows $8+12$ ). Therefore, we checked for the variance inflation factors to ensure the absence of multicollinearity issues.

[TABLE 3 ABOUT HERE]

\section{Analysis and results}

In this section, we test our hypotheses to determine what drives investment decisions and the 
extent to which social interactions and gender help explain these decisions. In doing so, we provide insights into the theoretical framework that can explain such behavior and, in particular, whether behavioral aspects are at play.

In Table 4, we test differences in sociability (H1a and $\mathrm{H} 1 \mathrm{~b})$ and gender (H2a and $\mathrm{H} 2 \mathrm{~b})$. The dependent variable is the natural logarithm of the amount invested by a given crowd investor (In(Amount Invested)). Regressions (1) and (2) use the full sample. All specifications include sector and year dummies. Thus, the variable Investment Type ( $1=$ Equity) captures only one real estate company undertaking an equity crowdfunding campaign, as réported in Table 2, Panel B. Regressions (3) and (4) use the subsample of equity crowdfunding, while Regressions (5) and (6) are restricted to bond investments.

\section{[TABLE 4 ABOUT HERE]}

We find that, all else being equal, investors living in more sociable areas tend to invest significantly more. We observe this result for our two measures Sociability1 and Sociability2. Importantly, we obtain positive and significant coefficients for our two measures of sociability, even after controlling for the social networks of the entrepreneurs. In line with previous literature (Vismara, 2016), we find a positive and significant coefficient for the measure of social capital of the entrepreneur (LinkedIn connections). The impact of social interactions is economically significant, as a one standard deviation increase of Sociabilityl leads to an increase in investments of EUR 28 and to an increase of EUR 40 for a one standard deviation increase of Sociability2 (compared with an average amount; i.e., around the mean of Amount Invested). These results provide support for H1a. Moreover, when we split the subsamples, this effect is significant only for equity (Regressions (3) and (4)), though it is positive for both equity and real estate projects. For equity, the economic significance is strong, with an increase of EUR 43 for a one standard deviation increase of Sociability2 around the mean Amount 
Invested, while for bond, it is close to zero. These results provide support for H1b, which predicts that the influence of social interactions is stronger for an equity investment than for a real estate bond investment. Moreover, it suggests that social interactions influence the way people invest. Investors who Hong et al. (2004) label as "socials" (i.e., those with high social interactions) tend to invest more, as evidenced here for equity crowdfunding.

As a robustness check, we control for the influence of geographic proximity, as an apparent effect of social interactions could result from people's tendency to invest in closer firms (Agrawal et al., 2015). We do this for all equity crowdfunding campaign because, here, we know the exact location of investors and the start-up. To calculate geographic distance between start-ups and investors, we use Coval and Moskowitz's (1999) formula based on latitudes and longitudes that we obtain by matching postal codes. We only calculate distances for investors located in Metropolitan France (i.e., we exclude French territories outside Europe and all investors outside France), as they allow for a more meaningful comparison. We find that geographic distance does not affect investments (results are not reported for the sake of space but are available on request). We obtain this result using distance in kilometers and for any meaningful binary transformation (e.g., whether the distance is less than $100 \mathrm{~km}$, but we check other values as well). These results are in line with the literature (Mollick, 2014).

In addition, informing investors about the ongoing investment status of the campaign (the variable Inv. Status Available) is associated with larger investments. Until October 17, 2014, individuals visiting a campaign website could see how much had been raised so far, while the campaign was ongoing. After that date, this information was no longer provided, so individuals no longer know the current status of the campaign in terms of amounts raised so far. A possible reason is that this removal increases the uncertainty around the success of the campaign, so investors, conditional on making an investment, invest less because of increased risk. 
Table 4 further tests determinants of investments to provide empirical support for $\mathrm{H} 2 \mathrm{a}$ and $\mathrm{H} 2 \mathrm{~b}$ on the impact of gender. We find that, on average, men invest larger amounts than women. In economic terms, the difference between men and women represents EUR 274.6 $(=0.276$ centered on the log-mean of 6.758), based on the most conservative result (Regression (1)). However, we obtain opposite results for equity and bonds. Men invest more than women in equity but less than women in bonds. This difference is consistent with the idea that men invest more when the asset is risky (equity) and less in safer assets (bonds) than women. These findings offer empirical support for both $\mathrm{H} 2 \mathrm{a}$ and $\mathrm{H} 2 \mathrm{~b}$. As mentioned previously, two explanations are possible: risk aversion and overconfidence. Subsequently, we perform a test to distinguish between these two explanations.

Analyses in Table 5 help further test whether men are more likely to reinvest (H1a). We run Probit regressions using a dummy variable that indicates whether a given investor made a follow-up investment. We run this analysis on the full sample, as well as on subsamples that exclude investors who made their first investment late. The regressions on subsamples are helpful in reducing sample biases with regard to investors who only recently began investing in equity and real estate bond crowdfunding on the given platform. In all our regressions, we find a strong and statistically significant impact of gender. Men have a $48 \%-58 \%$ greater probability of making a follow-up investment than women. This finding provides empirical support for H1a.

\section{[TABLE 5 ABOUT HERE]}

Next, we test $\mathrm{H} 3$ to determine what explains the gender difference. Table 4 shows that, ceteris paribus, men invest more than women and in riskier projects, consistent with $\mathrm{H} 2 \mathrm{a}$ and $\mathrm{H} 2 \mathrm{~b}$. Under $\mathrm{H} 3$, the driving force is overconfidence, which leads men to invest in less successful campaigns. A lack of support for $\mathrm{H} 3$ would suggest that differences in risk aversion is a more 
plausible explanation for this gender difference. In Table 6, we perform the tests along three related measures of successful campaign outcome. Ahlers et al. (2015) propose several measures of funding success (e.g., attainment of targeted amount, number of investors, funding amount, speed of completion of campaign). We chose to retain a success measure based on funding amount because the size of the minimum ticket directly influences the number of investors and the speed of completion depends on a project's chosen campaign duration, which varies in our sample. The first measure (used in Regressions (1)-(3)) uses the variable Funded Dummy, which equals 1 if the desired goal was achieved; the second measure (used in Regressions (4)-(6)) is a dummy variable that equals 1 if the Achieved Funding Ratio is larger than the 90th percentile (the most successful); finally, the third measure (used in Regressions (7)-(9)) is simply the Achieved Funding Ratio. We obtain consistent results in all the regressions, showing no gender effect in campaign outcome (i.e., men do not invest in campaigns that are less successful). Therefore, we find no empirical support for H3. Instead, we conclude that the difference in risk aversion rather than overconfidence is more likely to explain the gender difference related to $\mathrm{H} 2 \mathrm{a}$ and $\mathrm{H} 2 \mathrm{~b}$, but we need to handle these results and this conclusion with care, because our outcome measures are imperfect proxies of success. To completely rule out the effect of overconfidence, we should use projects' rates of return, which are unfortunately unavailable because of the young age of funded firms.

\section{[TABLE 6 ABOUT HERE]}

Finally, in Table 6 we do not report specifications that include our sociability measures because they are never statistically significant. More sociable investors are not more likely to invest in more successful campaigns. However, we do control for the social capital of the entrepreneur (LinkedIn connections), which is positively linked to the outcome of a campaign in equity crowdfunding. This result is consistent with that obtained in previous research (Vismara, 2016), 
indicating that social capital helps attract more investors.

\section{Discussion and conclusion}

This paper contributes to the entrepreneurship and finance literature by examining investmentbased crowdfunding from a buy-side (investor) perspective, based on a new and rich database that includes investment- and investor-level information. Our reliance on two types of funding schemes (equity and bond) provides us with several research opportunities. Most important, we are able to take social factors into consideration, which allows us to draw a richer picture of investment behavior in crowdfunding. We find that social interactions have a strong influence on investors' choices, as crowd investors who are more often involved in social interactions in their daily lives invest larger amounts in campaigns. Moreover, their influence is especially strong in equity crowdfunding, whose objective is to help entrepreneurs in their quest to develop a business. Our results show that social interactions counteract the uncertainty surrounding equity crowdfunding, as indicated by our results that more sociable crowd investors pledge higher amounts in risky securities (i.e., in equity of innovative and entrepreneurial start-ups). From the perspective of the entrepreneur and the platform, this result is important because it provides a way to raise funding during a campaign by alleviating the uncertainty with tools (e.g., social network activities, live shows permitting interactions with the crowd) that increase social interactions. Such tools promote a sense of belonging that crowd investors have when they invest in equity.

We also find that men invest larger amounts and in riskier projects than women. Our analysis suggests that this is best explained by differences in risk aversion, consistent with Mohammadi and Shafi's (2018) conclusions but with different identification strategies for capturing differences in risk aversion. Mohammadi and Shafi note that one limitation of their findings is the difficulty of generalizing their results with a single platform in one country. We provide 
further evidence of a lower risk aversion of women investing in equity crowdfunding. Therefore, our study complements theirs in this respect.

Our research has some limitations that at the same time offer avenues for future research. Most notably, we found that investment choices in crowdfunding are better explained by differences in risk preference and that outcomes of investment choices (measured by campaign success in relation to the declared funding goal) are not influenced by gender. In other words, men inyest more in risky projects, but risky projects do not exhibit worse campaign performance in terms of raised capital. These rough proxies for the success of a campaign contribute to a rationalitybased explanation, but they do not provide us with a definite conclusion. Instead, we need to use the performance of investment choices (i.e., the return of each start-up or real estate project) and calculate risk-adjusted returns. We could not investigate these issues herein because of the difficulty of obtaining such data and because these investments are too recent to obtain good return estimates. However, further research could shed light on this issue.

A potential concern that we do not address is the question of homophily. Greenberg and Mollick (2016) and Vismara et al. (2017) provide notable results on this subject, showing that gender has an impact on the interaction between supply and demand. In other words, women tend to help other women seeking funding. Unfortunately, we are not able to investigate this question because all the start-ups in our sample are led by male CEOs.

Future research can extend our study in several ways. First, a detailed examination of individual crowdfunding dynamics seems to be a promising research avenue. Existing studies largely consider investment decisions in isolation, while finance theory shows the benefits of taking a portfolio perspective. Our collected sample of investments offers the unique ability to investigate dynamic strategies of building portfolios because we can track investors over time across the different crowdfunding campaigns. Second, our study can be extended by 
elaborating on several situational and network factors, such as minimum tickets and the number of competing investments. These factors are likely to influence crowdfunders' investments, but they merely served as control variables in our analysis. Similarly, textual analysis of campaign descriptions may offer new insights into how communications affect investors' choices and mitigate concerns about risk. Third, research could investigate the wisdom of the crowd more directly. The screening process at WiSEED involves an e-vote phase before allowing the startup to begin its fundraising campaign. Members of WiSEED assign several grades to different dimensions (e.g., sustainability, customers, business model) of the projects. A detailed examination of the link between the grades of the different attributes and ex post investor behavior during the campaign would convey important information on crucial investor concerns. This could help the platform improve its selection process and ex post matching by reinforcing the screening phase with feedback from current platform members through the evotes. Finally, data will need to be collected in the future about financial performance of equity crowdfunded firms. One exception that offers such ex post performance analysis is Signori and Vismara's (2018) work. Such studies would shed light on research questions such as whether equity crowdfunding is a viable investment asset and whether crowd investors make sound decisions. Our study can be extended to investigate whether sociability and, thus, social networks ultimately help start-ups achieve higher performance. 


\section{References}

Agnew, J. R. (2006). Do behavioral biases vary across individuals? Evidence from individual level 401 (k) data. Journal of Financial and Quantitative Analysis, 41(4), 939-962.

Agnew, J., Balduzzi, P., \& Sunden, A. (2003). Portfolio choice and trading in a large 401 (k) plan. American Economic Review, 93, 193-215.

Agrawal, A., Catalini, C., \& Goldfarb, A. (2015). Crowdfunding: Geography social, networks and the timing of investment decision, Journal of Economics and Management Strategy, 24(2), 253-274.

Ahlers, G. K., Cumming, D., Günther, C., \& Schweizer, D. (2015). Signaling in equity crowdfunding. Entrepreneurship Theory and Practice, 39(4), 955-980.

Barber, B. M., and Odean, T. (2001). Boys will be boys: Gender, overconfidence, and common stock investment. Quarterly Journal of Economics, 116(1), 261-292.

Bazerman, M. H., \& Moore, D. A. (2009). Judgment in managerial decision making $\left(7^{\text {th }}\right.$ ed.). New York: Wiley.

Becker-Blease, J. R., \& Sohl, J. E. (2011). The effect of gender diversity on angel group investment. Entrepreneurship Theory and Practice, 35(4), 709-733.

Benartzi, S. (2001). Excessive extrapolation and the allocation of $401(\mathrm{k})$ accounts to company stock. Journal of Finance, 56, 1747-1764.

Block. J. H., Colombo, M. G., Cumming, D. J., \& Vismara, S. (2018). New players in entrepreneurial finance and why they are there. Small Business Economics, 50(2), 239250.

Butticè, V., Colombo, M. G., \& Wright, M. (2017). Serial crowdfunding, social capital, and project success. Entrepreneurship Theory and Practice, 41(2), 183-207.

Cholakova, M., \& Clarysse, B. (2015). Does the possibility to make equity investments in crowdfunding projects crowd out reward-based investments?. Entrepreneurship Theory and Practice, 39(1), 145-172.

Colombo, M. G., Franzoni, C., \& Rossi-Lamastra, C. (2015). Internal social capital and the attraction of early contributions in crowdfunding. Entrepreneurship Theory and Practice, 39(1), 75-100.

Cosh, A., Cumming, D., \& Hughes, A. (2009). Outside entrepreneurial capital. The Economic Journal, 119(540), 1494-1533.

Coval, J. D., \& Moskowitz, T. J. (1999). Home bias at home: Local equity preference in domestic portfolios. Journal of Finance, 54, 2045-2073.

Croson, R., \& Gneezy, U. (2009). Gender differences in preferences. Journal of Economic Literature, 47(2), 448-474.

Cumming, D. J., Leboeuf, G., \& Schwienbacher, A. (2014). Crowdfunding models: Keep-itall vs. all-or-nothing. Retrieved from http://ssrn.com/abstract=2447567.

Duflo, E., \& Saez, E. (2002). Participation and investment decisions in a retirement plan: The influence of colleagues' choices. Journal of Public Economics, 85(1), 121-148.

Dunning, D., Griffin, D. W., Milojkovic, J. D., \& Ross, L. (1990). The overconfidence effect in social prediction. Journal of Personality and Social Psychology, 58(4), 568-581.

Estes, R., \& Hosseini, J. (1988). The gender gap on Wall Street: An empirical analysis of confidence in investment decision making. Journal of Psychology, 122(6), 577-590.

Faccio, M., Marchica, M.-T., \& Mura, R. (2016). CEO gender, corporate risk-taking, and the efficiency of capital allocation. Journal of Corporate Finance, 39, 193-209.

Freiburg, M., \& Grichnik, D. (2012). Institutional investments in private equity funds: social ties and the reduction of information asymmetry. Venture Capital, 14(1), 1-26.

Frydrych, D., Bock, A. J., Kinder, T., \& Koeck, B. (2014). Exploring entrepreneurial legitimacy in reward-based crowdfunding. Venture Capital, 16(3), 247-269. 
Giudici, G., Guerini, M., \& Rossi-Lamastra, C. (2013). Why crowdfunding projects can succeed: The role of proponents' individual and territorial social capital. Retrieved from $\mathrm{http}: / /$ ssrn.com/abstract $=2255944$.

Glaser, M., \& Weber, M. (2007). Overconfidence and trading volume. The Geneva Risk and Insurance Review, 32(1), 1-36.

Graham, J. R., Harvey, C. R., \& Puri, M. (2013). Managerial attitudes and corporate actions. Journal of Financial Economics, 109(1), 103-121.

Granovetter, M. (1983). The strength of weak ties: A network theory revisited. Sociological Theory, 1, 201-233.

Greenberg, J., \& Mollick, E. R. (2016). Leaning in or leaning on? Gender, homophily, and activism in crowdfunding. Retrieved from https://repository.upenn.edu/mgmt_papers/189/.

Grinblatt, M., \& Keloharju, M. (2001). How distance, language, and culture influence stockholdings and trades. Journal of Finance, 56, 1053-1073.

Guiso, L., Sapienza, P., \& Zingales, L. (2004). The role of social capital in financial development. American Economic Review, 94(3), 526-556.

Harrison, R. T., \& Mason, C. M. (2007). Does gender matter? Women business angels and the supply of entrepreneurial finance. Entrepreneurship Theory and Practice, 31(3), 445-472.

Hong, H., Kubik, J. D., \& Stein, J. C. (2004). Social interaction and stock-market participation. Journal of Finance, 59, 137-163.

Hong, H., Kubik, J. D., \& Stein, J. C. (2005). Thy neighbor's portfolio: Word-of-mouth effects in the holdings and trades of money managers. Journal of Finance, 60, 2801-2824.

Hornuf, L., \& Schwienbacher, A. (2016). Crowdinvesting: Angel investing for the masses?, In H. Landström \& C. Mason (Eds.), Handbook of research on business angels (Vol. 3, pp. 381-397). Cheltenham: Edward Elgar.

Hornuf, L., and Schwienbacher, A. (2017a). Market mechanisms and funding dynamics in equity crowdfunding. Journal of Corporate Finance, forthcoming.

Hornuf, L., and Schwienbacher, A. (2017b). Should Securities Regulation Promote Equity Crowdfunding? Small Business Economics 49 (3), 579-593.

Huang, J., \& Kisgen, D. J. (2013). Gender and corporate finance: Are male executives overconfident relative to female executives? Journal of Financial Economics, 108(3), 822839.

Hvide, H. K., \& Östberg, P. (2015). Social interaction at work. Journal of Financial Economics, $117(3), 628-652$.

Ivković, Z., \& Weisbenner, S. (2007). Information diffusion effects in individual investors' common stock purchases: Covet thy neighbors' investment choices. Review of Financial Studies, 20(4), 1327-1357.

Kahneman, D. (2011). Thinking, fast and slow. London: Macmillan.

Kaustia, M., \& Knüpfer, S. (2012). Peer performance and stock market entry. Journal of Financial Economics, 104(2), 321-338.

Kim, K., \& Hann, I. (2015). Does crowdfunding democratize access to finance? A geographical analysis of technology projects. Retrieved from http://ssrn.com/abstract=2334590.

Kuppuswamy, V., \& Bayus, B. L. (2013). Crowdfunding creative ideas: The dynamics of project backers in Kickstarter. UNC Kenan-Flagler Research Paper No. 2013-15.

Lin, M., Prabhala, N. R., \& Viswanathan, S. (2013). Judging borrowers by the company they keep: friendship networks and information asymmetry in online peer-to-peer lending. Management Science, 59(1), 17-35.

Malmendier, U., \& Tate, G. (2005). CEO overconfidence and corporate investment. Journal of Finance, 60, 2661-2700. 
Malmendier, U., \& Tate, G. (2008). Who makes acquisitions? CEO overconfidence and the market's reaction. Journal of Financial Economics, 89(1), 20-43.

Markowitz, H. (1959). Portfolio selection: Efficient diversification of investments. Cowles Foundation Monograph, (16).

Marom, D., Robb, A., \& Sade, O. (2016). Gender dynamics in crowdfunding (Kickstarter): Evidence on entrepreneurs, investors, deals and taste-based discrimination. Retrieved from http://ssrn.com/abstract=2442954.

McKenny, A. F., Allison, T. H., Ketchen, D. J., Short, J. C., \& Ireland, R. D. (2017). How Should Crowdfunding Research Evolve? A Survey of the Entrepreneurship Theory and Practice Editorial Board. Entrepreneurship Theory and Practice, 41(2), 291-304.

Mitchell, O. S., \& Utkus, S. P. (2006). How behavioral finance can inform retirement plan design. Journal of Applied Corporate Finance, 18(1), 82-94.

Mohammadi, A., \& Shafi, K. (2018). Gender differences in the contribution patterns of equity-crowdfunding investors. Small Business Economics, 50(2), 275-287.

Mollick, E. (2014). The dynamics of crowdfunding: An exploratory study. Journal of Business Venturing, 29(1), 1-16.

Ng, L., \& Wu, F. (2010). Peer effects in the trading decisions of individual investors. Financial Management, 39(2), 807-831.

Polzin, F., Toxopeus, H., \& Stam, E. (2018). The wisdom of the crowd in funding: information heterogeneity and social networks of crowdfunders. Small Business Economics, 50(2), 251-273.

Putnam, R. D. (2000). Bowling alone: The collapse and the revival of American democracy. New York: Simon \& Schuster.

Schwienbacher, A., \& Larralde, B. (2010). Crowdfunding of small entrepreneurial ventures. Retrieved from https://papers.ssrn.com/sol3/papers.cfm?abstract_id=1699183.

Shane, S., \& Cable, D. (2002). Network ties, reputation, and the financing of new ventures. Management Science, 48(3), 364-381.

Signori, A., \& Vismara, S. (2018). Does success bring success? The post offering lives of equity crowdfunded firms. Journal of Corporate Finance, 50, 575-591.

Simon, H. A. (1957). Models of man. New York: Wiley.

Skirnevskiy, V., Bendig, D., \& Brettel, M. (2017). The influence of internal social capital on serial creators' success in crowdfunding. Entrepreneurship Theory and Practice, 41(2), 209-236.

Statman, M., Thorley, S., \& Vorkink, K. (2006). Investor overconfidence and trading volume. Review of Financial Studies, 19(4), 1531-1565.

Sunden, A. E., \& Surette, B. J. (1998). Gender differences in the allocation of assets in retirement savings plans. American Economic Review, 88(2), 207-211.

Tsai, W., \& Ghoshal, S. (1998). Social capital and value creation: The role of intrafirm networks. Academy of Management Journal, 41(4), 464-476.

Tversky, A., \& Kahneman, D. (1974). Judgment under uncertainty: Heuristics and biases. Science, 185(4157), 1124-1131.

Vallone, R. P., Griffin, D. W., Lin, S., \& Ross, L. (1990). Overconfident prediction of future actions and outcomes by self and others. Journal of Personality and Social Psychology, $58(4), 582-592$.

Vismara, S. (2016). Equity retention and social network theory in equity crowdfunding. Small Business Economics, 46(4), 579-590.

Vismara, S. (2018). Information cascades among investors in equity crowdfunding. Entrepreneurship Theory and Practice, 42(3), 467-497. 
Vismara, S., Benaroio, D., \& Carne, F. (2017). Gender in entrepreneurial finance: Matching investors and entrepreneurs in equity crowdfunding. In A. N. Link (Ed.), Gender and entrepreneurial activity (pp. 271-288). Cheltenham: Edward Elgar.

Zacharakis, A. L., \& Shepherd, D. A. (2001). The nature of information and overconfidence on venture capitalists' decision making. Journal of Business Venturing, 16(4), 311-332. 
Table 1 Definition of variables

Variable

Definition

\section{Investor Characteristics}

Gender (1=man)

Investor Age (years)

Amount Invested $(€)$

Days Elapsed since Campaign Start (days)

First Days of Campaign (dummies)

Nbr. Investments Made (nbr)

Amount Invested in ECF

Amount invested in Bond

\section{Firm/Project Characteristics}

Firm Age (years)

LinkedIn Connections

Start-up Sector (dummy)
Dummy variable that takes a value of 1 if the investor is a man, and 0 otherwise. (Source: WiSEED)

The age of investor in years at time of investment. This variable is constructed as the difference between the investor's exact investment date and birth date. (Source: WiSEED; own calculation) Amount in euros invested by a given investor in a given campaign. (Source: WiSEED)

Number of days elapsed between the actual investment and campaign start. (Source: WiSEED; own calculation)

Set of three dummy variables that take a value of 1 if the investment was made during the first, second, or third day of the campaign, and 0 otherwise. (Source: WiSEED; own calculation)

Number of investments made by a given investor so far. This variable is calculated from the portfolio that each investor has built on the WiSEED platform since its start. (Source: WiSEED) Total amount invested (in euros) by a given investor in all the equity crowdfunding (ECF) campaigns so far on WiSEED. (Source: WiSEED)

Total amount invested (in euros) by a given investor in all bond-like real estate campaigns so far on WiSEED. (Source: WiSEED)

Age of the firm in years at time of investment. This variable is only calculated for equity crowdfunding. (Source: WiSEED; own calculation)

Number of LinkedIn connections of the founding team divided by 100 . We apply the same methodology as Colombo et al. (2015). Searches on first name, last name, and profession of project proponents were conducted on LinkedIn. In case of multiple founders, we take the average number of their LinkedIn connections. This information is available only for ECF projects. (Source: WiSEED; LinkedIn)

Dummy variable that takes a value of 1 if the firm is active in the considered sector, and 0 otherwise. Considered sectors are Health, Environment, Industry \& Service, Information and Communication Technology (ICT), and Real Estate. All real estate projects are categorized in the last sector, while equity crowdfunding campaigns can be categorized in any of these sectors, including real estate. (Source: WiSEED) 


\section{Location and Social Characteristics}

Investor Location (dummy)

Start-up Location: Population (nbr)

Inv. Location: Sociability1

Inv. Location: Sociability2

Inv. Location: Population (nbr)

$(€)$

Inv. Location: Education 2012
Dummy variable that takes a value of 1 if the investor is located in a given country, and 0 otherwise. Considered countries are France, Switzerland, and Belgium. Other countries are also included in the sample but treated here as "other." (Source: WiSEED)

Population in number of inhabitants (in thousands) in the city of the start-up/firm. This value corresponds to the population registered in the postal code (zip code) of the firm's location. (Source: WiSEED for postal codes of investors; INSEE for population statistics)

Level of sociability in the area the investor lives in (based on population size) and based on the investor's gender. The index measures the average time (in minutes per day) a person spends in a social activity. Values are provided by the data source for the population size ranges $1-9,999$, 10,000-49,999, 50,000-199,999, 200,000-1,999,999, and for Paris separately. The index is calculated for men and women separately. A higher value of this measure corresponds to greater sociability. (Source: INSEE; http://www.insee.fr/fr/themes/detail.asp?reg_id=0\&ref_id=iredt2010\&page=irweb/edt2010/dd/edt2010_loisirs36.htm)

Alternative measure of the level of sociability in the area the investor lives in (based on population size) and based on the investor's gender. The index measures the percentage of the population that engages in any social activity. Values are provided by the data source for the population size ranges $1-9,999,10,000-49,999,50,000-199,999,200,000-1,999,999$, and for Paris separately. The index is calculated for men and women separately. A higher value of this measure corresponds to greater sociability. (Source: INSEE; http://www.insee.fr/fr/themes/detail.asp?reg_id=0\&ref_id=iredt2010\&page $=$ irweb/edt2010/dd/edt2010 loisirs36.htm)

Population in number of inhabitants (in thousands) in the city of the investor, in natural logarithm. This value corresponds to the population registered in the postal code (zip code) of the investor's location. (Source: WiSEED for postal codes of investors; INSEE for population statistics; data on population: $\quad \mathrm{http} / / / \mathrm{www}$.insee. $\mathrm{fr} / \mathrm{fr} / \mathrm{ppp} / \mathrm{bases}-\mathrm{de}-\mathrm{donnees} /$ recensement/populationslegales/france-departements.asp?annee $=2010)$

Average household revenues in euros (net of social security contributions but gross of income taxes) in 2011 of the population living in the same postal code as the investor. (Source: INSEE, calculated as the ratio of RNETFF11 over NBFF11)

Level of education of the population living in the same postal code as the investor. The measure corresponds to the fraction of the population in 2012 that holds an educational degree. (Source: INSEE, calculated as ([P12_NSCOL15P_CEP $\quad+$ P12_NSCOL15P_BEPC + 


\section{Campaign Characteristics}

Desired Funding $(€)$

Minimum Ticket $(€)$
Investment Type ( $1=$ Equity)

Total Amount Raised (€)

Total Number of Investments (nbr)

Achieved Funding Ratio (=Raised/Desired)

Funded Dummy (1=yes)

Campaigns Started in 20XX (dummy)

Inv. Status Available (1=yes)

Nbr. Competing Investments (nbr)
P12_NSCOL15P_CAPBEP + P12_NSCOL15P_BAC + P12_NSCOL15P_BACP2 +

P12_NSCOL15P_SUP] / [P12_POP1517 + P12_POPי̄1824 + P12_POP2529 + P12_POP30P])

The desired funding of the project or firm, in euros. Because all the campaigns are run under the keep-it-all model, this value is not the minimum required but the targeted funding level. (Source: WiSEED)

The minimum amount in euros that an investor needs to invest in a campaign. This value varies across campaigns, except for real estate projects. (Source: WiSEED)

Dummy variable that takes a value of 1 if the type of investment is equity (i.e., an equity crowdfunding campaign), and 0 if the type of investment is a bond campaign. (Source: WiSEED)

Sum of all individual investments made during a given campaign, measured at the end of the campaign. (Source: WiSEED)

Total number of investments made by all the investors during the course of a campaign. This value corresponds to the aggregated number of individual investments and thus is calculated at the end of the campaign. (Source: WiSEED)

Ratio of "Total Amount Raised" to "Desired Funding." (Source: WiSEED; own calculation)

Dummy variable that takes a value of 1 if the variable "Achieved Funding Ratio" is greater or equal to 1 , and 0 otherwise. (Source: WiSEED; own calculation)

Set of dummy variables that takes a value of 1 if the campaign was started in 20XX, and 0 otherwise, where 20XX ranges from 2009 to 2015. (Source: WiSEED)

Dummy variable that takes a value of 1 if the platform WiSEED informs investors about the status of investments made so far, and 0 otherwise. In this case, the information provided is the total amount of investments made so far, which indicates whether the firm is close to achieving its desired funding or has attracted more than that level. This information was provided on the website of each campaign until October 17, 2014, but not after. (Source: WiSEED)

Number of other investments made on the same day in any campaign run on WiSEED. (Source: WiSEED; own calculation) 
Table 2 Sample summary statistics

This table presents summary statistics on the main variables used in this study. All the variables are defined in Table 1. Panel A reports statistics at the investment level, Panel B at the campaign level (one observation per campaign only) for equity crowdfunding campaigns, and Panel $\mathrm{C}$ at the campaign level for bond crowdfunding campaigns.

\begin{tabular}{|c|c|c|c|c|c|c|}
\hline \multicolumn{7}{|c|}{ Panel A: Characteristics of investors, investment-level statistics } \\
\hline Variables & Nbr. Obs. & Mean & Std. Dev. & Median & Minimum & Maximum \\
\hline Investor Age (years) & 10115 & 43.361 & 12.203 & 42.089 & 17.944 & 89.681 \\
\hline Gender $(1=$ man $)$ & 10142 & 0.930 & 0.254 & 1 & 0 & 1 \\
\hline Amount Invested $(€)$ & 10142 & 2149.3 & 5316.2 & 1000 & 100 & 154000 \\
\hline Investment Type (1=Equity) & 10142 & 0.731 & 0.443 & 1 & 0 & 1 \\
\hline Days Elapsed Since Campaign Start (days) & 10142 & 33.455 & 35.817 & 21 & 0 & 180 \\
\hline Investor Location: France (dummy) & 10138 & 0.921 & 0.269 & 1 & 0 & 1 \\
\hline Investor Location: Switzerland (dummy) & 10138 & 0.017 & 0.130 & 0 & 0 & 1 \\
\hline Investor Location: Belgium (dummy) & 10138 & 0.014 & 0.118 & 0 & 0 & 1 \\
\hline Nbr. Competing Investments (nbr) & 10142 & 0.482 & 2.907 & 0 & 0 & 32 \\
\hline For Investors Located in France: & & & & & & \\
\hline Inv. Location: Sociability1 & 9257 & 11.374 & 1.676 & 11 & 10 & 15 \\
\hline Inv. Location: Sociability2 & & 16.951 & 1.872 & 18 & 14 & 21 \\
\hline Inv. Location: Population (nbr) & 9289 & 368.7 & 751.8 & 25.3 & 0.1 & 2243.8 \\
\hline Inv. Location: Avg. Revenues $2011(€)$ & 8764 & 31181.7 & 10304.1 & 28248.2 & 12679.2 & 96609.7 \\
\hline Inv. Location: Education 2012 & 8796 & 0.358 & 0.036 & 0.355 & 0.214 & 0.593 \\
\hline
\end{tabular}




\begin{tabular}{|c|c|c|c|c|c|c|}
\hline \multicolumn{7}{|c|}{ Panel B: Characteristics of equity crowdfunding campaigns, campaign-level statistics } \\
\hline Variable & Nbr. Obs. & Mean & Std. Dev. & Median & Minimum & Maximum \\
\hline Firm Age (years) & 76 & 3.671 & 2.599 & 3 & 0 & 11 \\
\hline LinkedIn Connections & 76 & 3.865 & 1.841 & 5 & 0 & 5 \\
\hline Minimum Ticket $(€)$ & 76 & 997.8 & 1568.8 & 300 & 100 & 5000 \\
\hline Total Amount Raised $(€)$ & 76 & 151207.0 & 133489.8 & 114700 & 0 & 742530 \\
\hline Total Number of Investments (nbr) & 76 & 92.47 & 106.18 & 50 & 0 & 592 \\
\hline Desired Funding $(€)$ & 76 & 244039.5 & 196371.0 & 150000 & 100000 & 1000000 \\
\hline Achieved Funding Ratio (=Raised / Desired) & 76 & 0.737 & 0.585 & 0.598 & 0 & 3.860 \\
\hline Funded Dummy (1=yes) & 76 & 0.237 & 0.428 & 0 & 0 & 1 \\
\hline Campaigns Started in 2009 (dummy) & 76 & 0.039 & 0.196 & 0 & 0 & 1 \\
\hline Campaigns Started in 2010 (dummy) & 76 & 0.105 & 0.309 & 0 & 0 & 1 \\
\hline Campaigns Started in 2011 (dummy) & 76 & 0.053 & 0.225 & 0 & 0 & 1 \\
\hline Campaigns Started in 2012 (dummy) & 76 & 0.079 & 0.271 & 0 & 0 & 1 \\
\hline Campaigns Started in 2013 (dummy) & 76 & 0.145 & 0.354 & 0 & 0 & 1 \\
\hline Campaigns Started in 2014 (dummy) & 76 & 0.368 & 0.486 & 0 & 0 & 1 \\
\hline Campaigns Started in 2015 (dummy) & 76 & 0.211 & 0.410 & 0 & 0 & 1 \\
\hline Start-up Sector: Health (dummy) & & 0.145 & 0.354 & 0 & 0 & 1 \\
\hline Start-up Sector: Environment (dummy) & 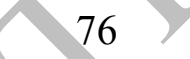 & 0.303 & 0.462 & 0 & 0 & 1 \\
\hline Start-up Sector: Industry \& Service (dun & 76 & 0.263 & 0.443 & 0 & 0 & 1 \\
\hline Start-up Sector: ICT (dummy) & 76 & 0.263 & 0.443 & 0 & 0 & 1 \\
\hline Start-up Sector: Real Estate (dummy) & 76 & 0.026 & 0.161 & 0 & 0 & 1 \\
\hline
\end{tabular}


Panel C: Characteristics of bond campaigns, campaign-level statistics

\begin{tabular}{lcccccc}
\hline Variable & Nbr. Obs. & Mean & Std. Dev. & Median & Minimum & Maximum \\
\hline & & & & & & \\
Minimum Ticket $(€)$ & 21 & 1000.000 & 0.000 & 1000 & 1000 & 1000 \\
Total Amount Raised $(€)$ & 21 & 384904.8 & 241855.3 & 380000 & 0 & 1000000 \\
Total Number of Pledges & 21 & 115.571 & 77.507 & 95 & 23 & 257 \\
Funding Goal (€) & 21 & 432904.8 & 284002.1 & 400000 & 66000 & 1000000 \\
Funding Ratio (=Raised / Goal) & 21 & 1.048 & 0.580 & 1 & 0 & 3.333 \\
Funded Dummy (1=yes) & 21 & 0.667 & 0.483 & 1 & 0 & 1 \\
Campaigns Started in 2009 & 21 & 0.000 & 0.000 & 0 & 0 & 0 \\
Campaigns Started in 2010 & 21 & 0.000 & 0.000 & 0 & 0 & 0 \\
Campaigns Started in 2011 & 21 & 0.000 & 0.000 & 0 & 0 & 0 \\
Campaigns Started in 2012 & 21 & 0.000 & 0.000 & 0 & 0 & 0 \\
Campaigns Started in 2013 & 21 & 0.095 & 0.301 & 0 & 0 & 1 \\
Campaigns Started in 2014 & 21 & 0.143 & 0.359 & 0 & 0 & 1 \\
Campaigns Started in 2015 & 21 & 0.762 & 0.436 & 1 & 0 & 1 \\
& & & & & & 0 \\
\hline
\end{tabular}


Table 3 Pairwise correlations

This table shows pairwise correlations between the main variables of interest. Significance levels: * for $1 \%$.

[1] Investor Age

[2] [3] [4] [5] $[6]$

[7]

[9]

[10]

[11]

$[12]$

[2] Gender (1=man)

[3] Amount Invested

[4] Investment Type (1=Equity)

[5] Days Elapsed Since Campaign Start

[6] Investor Location: France

[7] Nbr. Competing Investments

[8] Inv. Location: Sociability1

[9] Inv. Location: Sociability2

[10] Inv. Location: Population

1
$-0.102 * \quad 1$

$0.161 * \quad-0.023$

$-0.036^{*} \quad-0.030^{*} \quad-0.164 *$

$-0.017-0.027 *$

$0.061 * \quad-0.047 *$

$0.051 * \quad-0.005$

$-0.102 *$

$-0.002$

0.004

$-0.163^{*}$

$0.060^{*}$

$-0.324 * 0.019$

0.001

$0.532 *$

$-0.002$

$\begin{array}{lll}-0.106 * & -0.062 * & 0.002\end{array}$

0.001

$-0.038^{*}$

$0.029 *$

$-0.008$

[11] Inv. Location: Avg. Revenues 2011

$0.112 * \quad-0.006$

$0.035 *-0.004$

0.013

[12] Inv. Location: Education 2012

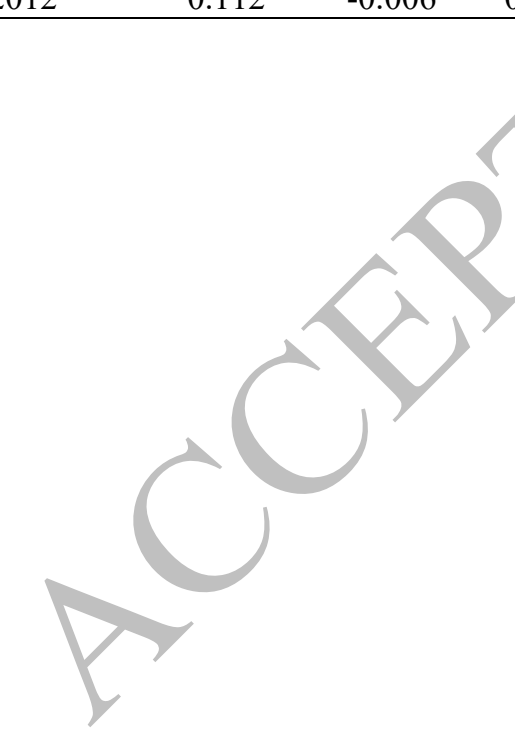


TABLE 4 Determinants of investment amount

The dependent variable is the natural logarithm of Amount Invested, which corresponds to the amount pledged by the investor (in euros) in a given campaign. This variable is winsorized for this analysis at the upper 3\% level. Regressions (1)-(2) use the full sample, Regressions (3)-(4) the sample of equity campaigns only, and Regressions (5)-(6) the sample of investments in real estate only. The full sample includes all investments made by investors located in France for which the sociability measures (and others) could be obtained. Robust standard errors are used. Significance levels: *** for $1 \%$, ** for $5 \%$, * for $1 \%$.

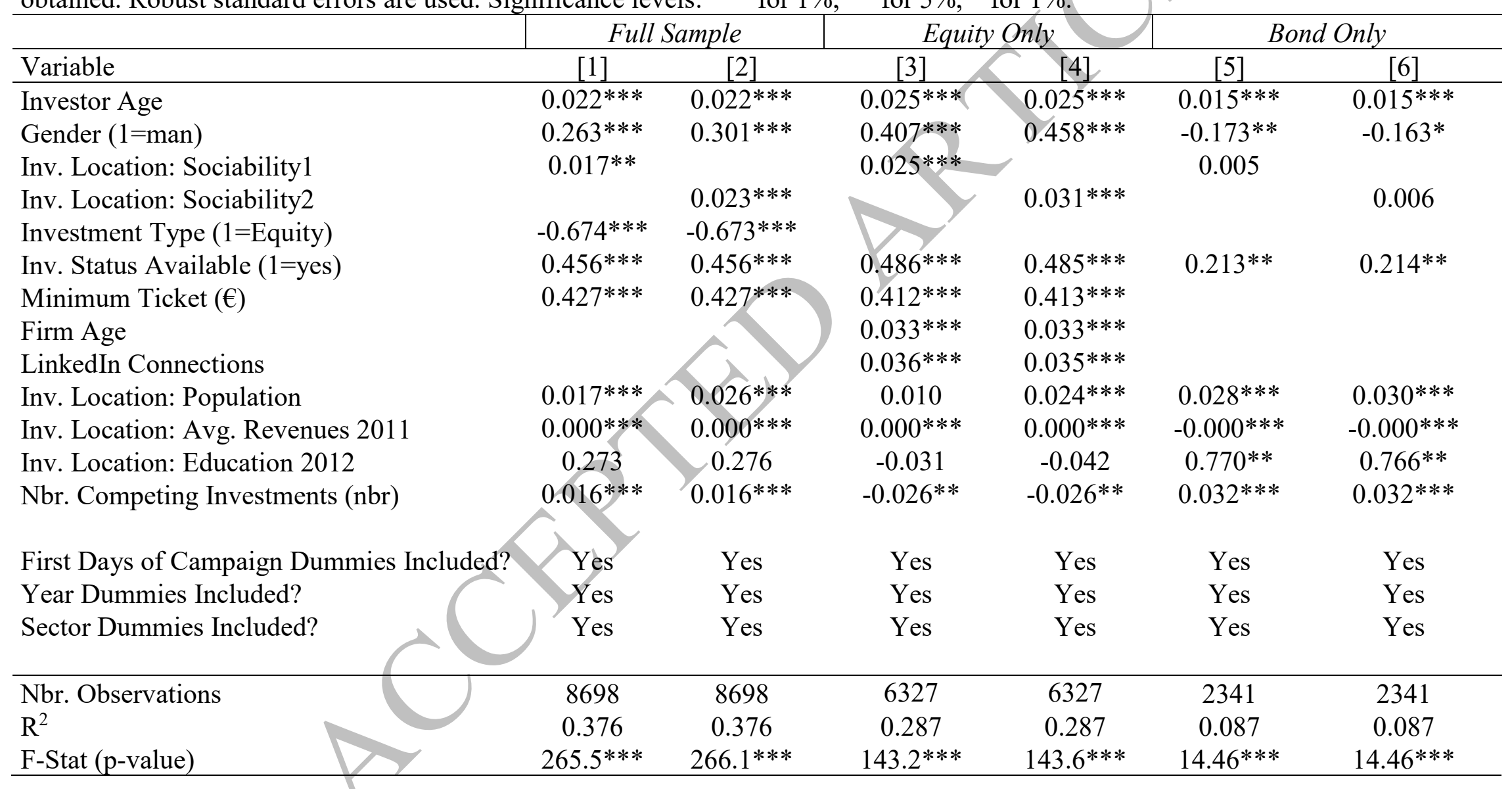


Table 5 Probability of a follow-up investment

The dependent variable is a dummy variable equal to 1 if the investor makes at least one more investment, and 0 otherwise. The analysis is done at the investor level (i.e., one observation per investor). Regression (1) uses the full sample of investors, Regression (2) only investors who have made their first investment before 2015, Regression (3) only investors who have made their first investment before 2014, and Regression (4) only investors who have made their first investment before 2013. Robust standard errors are used. Significance levels: *** for $1 \%, * *$ for $5 \%, *$ for $10 \%$.

\begin{tabular}{|c|c|c|c|c|}
\hline Variable & [1] & [2] & [3] & [4] \\
\hline & Full Sample & Up to 2014 & Up to 2013 & Up to 2012 \\
\hline Investor Age at First Inv. & $0.003 * *$ & $0.005 * *$ & $0.012 * * *$ & $0.018 * * *$ \\
\hline Gender $(1=$ man $)$ & $0.478 * * *$ & $0.539 * * *$ & $0.484 * * *$ & $0.581 * * *$ \\
\hline Investor Location: France & $-0.223 * * *$ & $-0.236^{*}$ & $-0.434 *$ & -0.523 \\
\hline Amount Invested at First Inv. & -0.000 & -0.000 & Y -0.000 & 0.000 \\
\hline Investment Type: Equity at First Inv. & $-0.334 * * *$ & 150 & -0.081 & -- \\
\hline Year Dummies (at First Inv.) Included? & & & Yes & Yes \\
\hline Nbr. Observations & 3773 & 1915 & 705 & 396 \\
\hline Pseudo-R ${ }^{2}$ & 03 & 0.030 & 0.039 & 0.050 \\
\hline Wald $\chi^{2}$ (p-value) & & $73.69 * * *$ & $34.20 * * *$ & $25.80 * * *$ \\
\hline
\end{tabular}


Table 6 Determinants of campaign outcome

The dependent variable in Regressions (1)-(3) is a dummy variable Funded Dummy equal to 1 if the firm achieves the desired funding goal, and 0 otherwise. The dependent variable in Regressions (4)-(6) is a dummy variable equal to 1 if the campaign's yalue of Achieved Funding Ratio (=Raised / Desired) at the end of the campaign is in the top $10 \%$ of the distribution (i.e., among the most successful campaigns), and 0 otherwise. Regressions (1)-(6) are Probit regressions, and Regressions (7)-(9) are ordinary least squares regressions. The dependent variable in Regressions (7)-(9) is the variable Achieved Funding Ratio at the end of the campaign. Regressions (1), (4), and (7) use the full sample; Regressions (2), (5), and (8) use the sample of equity crowdfunding campaigns only; and Regressions (3), (6), and (9) use the sample of bond crowdfunding campaigns only. Robust standard errors are used. Significance levels: *** for $1 \%, * *$ for $5 \%, *$ for $10 \%$.

\begin{tabular}{|c|c|c|c|c|c|c|c|c|c|}
\hline \multirow[b]{2}{*}{ Variable } & \multicolumn{3}{|c|}{ Dep. Var. $=$ Funded Dummy } & \multicolumn{3}{|c|}{$\begin{array}{c}\text { Dep. Var. = Achieved Funding } \\
\text { Ratio }>\text { Top } 10 \% \text { (Dummy) }\end{array}$} & \multicolumn{3}{|c|}{$\begin{aligned} \text { Dep. } \text { Var. }= & \text { Achieved Funding } \\
& \text { Ratio }\end{aligned}$} \\
\hline & [1] All & [2] Equity & [3] Bond & [4] All & [5] Equity & [6] Bond & [7] A11 & [8] Equity & [9] Bond \\
\hline Investor Age & $0.001 * *$ & $0.002 * * *$ & $-0.002 * * *$ & $0.001 * * *$ & $0.001 * * *$ & 0.000 & $0.001 * * *$ & $0.002 * * *$ & -0.000 \\
\hline Gender $(1=$ man $)$ & -0.008 & -0.006 & -0.008 & 0.001 & -0.004 & 0.029 & 0.002 & -0.007 & 0.010 \\
\hline Investor Location: France $(1=$ yes $)$ & 0.013 & 0.013 & 0.021 & $0.024 * *$ & $0.030 * *$ & 0.005 & 0.015 & 0.008 & 0.007 \\
\hline Investment Type (1=Equity) & $1.517 * * *$ & & & $0.445 * * *$ & & & $0.232 * * *$ & & \\
\hline Firm Age & & $-0.051 * * *$ & & & $-0.015 * * *$ & & & $-0.006 * * *$ & \\
\hline LinkedIn Connections & & $0.112 * * *$ & & & $0.049 * * *$ & & & $0.021 * * *$ & \\
\hline Minimum Ticket $(€)$ & $0.027 * * *$ & 0.013 & & $0.029 * * *$ & $0.024 * * *$ & & $0.012 * * *$ & $0.026 * * *$ & \\
\hline Inv. Status Available (1=yes) & $-0.077 * * *$ & & & $0.199 * * *$ & $0.181 * * *$ & $0.087 * * *$ & $0.100 * * *$ & $0.047 * * *$ & $0.601 * * *$ \\
\hline $\begin{array}{l}\text { First Days of Campaign Dummies } \\
\text { Included? }\end{array}$ & Yes & & Yes & Yes & Yes & Yes & Yes & Yes & Yes \\
\hline Year Dummies Included? & Yes & Yes & No & Yes & Yes & No & Yes & Yes & No \\
\hline Sector Dummies Included? & & Yes & Yes & Yes & Yes & Yes & Yes & Yes & Yes \\
\hline Nbr. Observations & 10112 & 7392 & 2720 & 10112 & 7392 & 2720 & 10112 & 7392 & 2720 \\
\hline (Pseudo) $\mathrm{R}^{2}$ & & 0.284 & 0.044 & 0.340 & 0.423 & 0.062 & 0.172 & 0.194 & 0.168 \\
\hline Wald $\chi^{2}(p$-value $)$ & - & $2448.5 * * *$ & $149.5 * * *$ & $5407.0 * * *$ & $4974.9 * * *$ & $2533.1 * * *$ & -- & -- & -- \\
\hline F-Stat (p-value) & & -- & -- & -- & -- & -- & $292.5 * * *$ & $249.7 * * *$ & $19.9 * * *$ \\
\hline
\end{tabular}

